(C) Шевчук С.Г., Шанчук М.О., 2019

doi: $10.37321 /$ nefrology.2019.25-11

УДК 61(477)

\title{
Ф.Г. ЯнОВСьКИЙ: СТОРІНКИ ЖИТТЯ, ЗДОБУТКИ В НЕФРОЛОГІЇ
}

\author{
С.Г. ШЕВЧУК, М.О. ШАНЧУК \\ Кафедра пропедевтики внутрішньої медицини №2 \\ Національного медичного університету імені О.О. Богомольця, Київ
}

Резюме. Мета роботи - ретроспективний аналіз історії Київської терапевтичної школи та внесок Ф.Г. Яновського в розвиток нефрології.

Матеріали і методи: нами було проведено знайомство та ретроспективний аналіз архівних матеріалів в тому числі друкованих праць Ф.Г. Яновського стосовно методів обстеження, діагностики та лікування хвороб нирок, зокрема нефритів в його клініці.

Висновки: з огляду на актуальність питань сучасної нефрології та поглядів на новітні підходи до діагностики та мистецтва лікування хвороб нирок цікаво ознайомити майбутніх лікарів та науковців з роллю особистості та історичними аспектами в медичній науці.

Ключові слова: семіотика хвороб нирок, нефрит, функціональна діагностика, Феофіл Гаврилович Яновський.

Вступ. Один із засновників Київської терапевтичної школи Феофіл Гаврилович Яновський народився 12 червня 1860 року у м. Миньківці, на території сучасної Хмельниччини в сім'ї службовця. 3 біографічних моментів слід підкреслити, що ще під час навчання на медичному факультеті Університету Св. Володимира виявлялися неабиякі здібності студента, якому без сумніву поталанило з викладачами, хоча і сам він відповідально використовував кожну хвилину і таким чином брав від навчання все, що було можна.

Після закінчення університету талановитий учень на диво залишився без роботи, тому мав потребу в пошуку «підробіток». Спочатку він просто працював лікарем, також був запрошений в якості асистента на домашні прийоми Карлом Генріховичем Тритшелем, працював у лазареті Києво-Подільської духовної школи, у Київському товаристві нічних чергувань. В останньому 3 часом обійняв посаду голови. Усі ці «підробітки» лікар шукав в основному не для матеріальної вигоди, а для здобуття лікарського досвіду, та через моральні принципи. Молодий лікар вважав, що маючи хоча б трохи вільного часу, він має присвятити його тим, хто потребує лікарської допомоги. Також якщо говорити на цю тему, вважаємо своїм обов'язком згадати випадки, коли Ф.Г. Яновський давав своїм пацієнтам гроші не тільки на ліки, але і на продукти харчування, які б сприяли видужанню. Такими поглядами він керувався впродовж всього свого життя. Надалі лікарська діяльність, яка починалася 3 жалюгідних нетрів Подолу, приносить йому значну славу та популярність в народі і навіть, маючи серед своїх пацієнтів таких відомих людей як Леся Українка, Микола Лисенко, Михайло Старицький, Петро Столипін та багато інших, Феофіл Гаврилович ніколи не забуває про нужденних. Саме через ці та багато інших фактів, про які написано безліч статей, в медичній спільноті початку XX століття Яновський Ф.Г. здобуває ім'я «лікарська совість», а в народі «святий лікар».

Мета. Ми ознайомились з науковою роботою та досягненнями Ф.Г. Яновського в медицині, зокрема в нефрології. За час своєї наукової діяльності стає автором 62 праць, в тому числі i монографій, а також робіт з питань діагностики та лікування інфекційних хвороб, туберкульозу, захворювань легень, нирок, шлунково-кишкового тракту, патології кровообігу тощо. Про його роботи написана велика кількість статей, але на нашу думку несправедливо обділені увагою праці в галузі нефрології, адже вклад його в розвиток цієї галузі сам по собі був значним, але, крім того, ще й стимулював подальші розробки висвітлених ним питань, що робить його насправді неоцінимим. Він набував досвіду в кращих клініках та лабораторіях Берліна та Парижа. Надалі, повернувшись до Києва, Феофіл Гаврилович засновує першу в місті та одну з найкращих у Російській імперії бактеріологічну лабораторію.

Матеріали і методи. Нами був проведений аналіз архівних матеріалів про роботи Феофіла Гавриловича Яновського в галузі нефрології. IHтерес вченого до ниркових хвороб виник ще в 1907 році після перенесеного ним самим гострого гломерулонефриту. Найважливішими напрямками його наукових інтересів були - діагностика, 
клініка, лікування і, в тому числі, дієтика ниркових хвороб.

Результати та їх обговорення. Перша визначна праця - «К семиотике острых нефритов» датується 1907 роком. Після публікації в Росії, вона була надрукована також у Франції, що свідчить про актуальність питань, над якими працював Ф.Г. Яновський. Вчений описує три відзначених ним симптоми, що мають, на його погляд, значну діагностичну та семіологічну роль при гострих нефритах.

Перший симптом - «осовелость» - він спостерігав велику кількість разів у пацієнтів психічні розлади, але звернув увагу особливо після власного інциденту захворювання. Поява симптому збігається з початком гострого нефриту, зі змінами складу сечі, але проявляється раніше всіх інших клінічних симптомів і характеризується проявами апатії. Пацієнт повною мірою усвідомлює все, що відбувається навколо нього, відповідає на всі запитання, не спостерігається також сповільнення розумових процесів, але не виявляє жодної зацікавленості до навколишнього середовища. Саме через це Феофіл Гаврилович дав йому таку, досить вульгарну на той час, назву. В праці симптом пояснюється проявом уремії. Щоправда, як пише сам Ф.Г. Яновський, це не пояснює суті описаного симптому, через нестачу на той час розуміння сутності уремії. Також частково цей прояв можна пояснювати стисненням судин набряковою рідиною (за теорією Л. Траубе). Хоча симптом виявляється не в кожному випадку гострого нефриту, але все ж має значне клінічне значення, адже, помітивши його, можна завчасно запідозрити початок захворювання нирок.

Наступною семіологічною ознакою Ф.Г. Яновський визначив набряк. 3 цього приводу він звертає увагу на значимість механічного фактора - еластичність тканин підшкірної клітковини. Ним і його співробітниками було помічено, що, за однакових масштабів ураження нирок, у пацієнтів з більш еластичною підшкірною клітковиною прояви набряків спостерігаються менш виражено, ніж у тих, в кого клітковина більш рихла. Також було помічено, що у пацієнтів, які раніше переносили набряки, прояви даного симптому також будуть більш значно виражені навіть при незначних порушеннях діяльності нирок, що знову ж таки пояснюється зниженням еластичних властивостей підшкірної клітковини. Виходячи 3 проведених спостережень, Феофіл Гаврилович вважає недоречним оцінювати ступінь ураження нирок за вираженістю набряків.

Третьою семіологічною ознакою $€$ задишка. Симптом цей часто виявляється за гострих нефритів, але Ф.Г. Яновський описує специфічний вид задишки. «Після того, як хворий з задоволенням спостерігає на собі зникнення одного за одним симптомів хвороби, йому тим неприємніше помічати впертість, з якою тримається останній симптом, залишок хвороби - задишка.». Описані випадки, в яких задишка тривала аж до 2 років після одужання. Пояснюється цей прояв «стомленням серця» (cor lassum), яке під час захворювання було перенавантажене через гіпертензію, також наводить як можливу причину анемію. Діагностичного значення, за очевидних причин, цей симптом позбавлений, але все ж має своє місце в семіотиці.

Феофіл Гаврилович та представники його школи звертають увагу на питання функціональної діагностики захворювань нирок. Свої особисті спостереження та результати досліджень своїх учнів він оголошує на IV з'їзді російських терапевтів (1912) у програмній доповіді «О способах функционального распознания почечных болезней», яку пізніше буде опубліковано в «Русском враче» №6 (1913). В основі даної роботи лежить детальний опис, аналіз та конструктивна критика наявних на той час та описаних у вітчизняній та зарубіжній літературі методик функціональної діагностики нирок: кріоскопія, рефрактометрія, водяна проба, біологічні дослідження та інші, які за оцінкою авторів не дають можливості оцінити функціональний стан нирок. Основна думка, яку висловлює вчений - це убогість і недосконалість тогочасних методів діагностики в цілому і в нефрології особливо. В самій доповіді на з'їзді терапевтів були також окреслені завдання подальших наукових розробок у цій галузі.

Не меншою актуальністю володіла програмна доповідь Ф.Г. Яновського на міжнародному фізіотерапевтичному конгресі в Берліні (1913) «К современному положенню диетики при нефритах», яка також була надрукована в «Русском Враче» №34 (1913). Дієтика при захворюваннях нирок і зокрема при нефритах була однією з найважливіших проблем, що розроблялись Ф.Г. Яновським та представниками його школи.

В доповіді було описано, проаналізовано та піддано критиці тогочасні положення про харчування хворих на нефрити. Дієта диктувала суворе та широке обмеження в продуктах харчування, наприклад, якщо заборонялися овочі, то всі без винятку. Такий принцип часто призводив до виснаження пацієнта, що згубно впливало на загальний стан та, що дуже важливо, настрій хворого. Посилаючись на власні спостереження та дослідження, проведені його учнями в клініці, Феофіл Гаврилович висуває нові важливі положення, які агітують притримуватися індивідуальності в питаннях дієтики та обґрунтовувати їі призначення, враховуючи патологію та порушення видільної здатності нирок стосовно різних хімічних речовин, а також зважати на хімічний склад продуктів харчування і способи кулінарної обробки.

Він розумів безумовну важливість впливу за- 
гального стану та настрою пацієнта на результат лікування хвороби і максимально прагнув вселити в пацієнта позитивні емоції.

Отже Яновським було зроблено значний внесок в розвиток дієтики при нефритах, нові положення завдяки введенню в раціон харчування приємних для пацієнта продуктів, що сприяли б покращенню загального емоційного стану хворих, а також попереджували розвиток виснаження, що спостерігалось при старих дієтах. Також не слід випускати з уваги, що цією доповіддю він звернув увагу світової лікарської спільноти на це важливе питання і стимулював дослідження в напрямку дієтології.

В двадцятих роках XX століття Феофіл Гаврилович та представники його школи значно розширюють діапазон своїх наукових досліджень у галузі нефрології. Вже в 1927 році була надрукована монографія «Диагностика заболеваний почек в связи с их патологией», яка була підсумком багаторічних спостережень і досліджень, власних і своїх сучасників, а також викладені були останні наукові досягнення, що мають значення в цій галузі.

Слід звернути увагу на написану в 1925 році і надруковану в «Врачебном деле» №7 того ж року працю «Клиническое значение запаха». Спочатку в своїй праці академік розказує власне про запахи, про специфічність запахів у людей певної національності, раси, навіть професії. В своїй роботі Феофіл Гаврилович описав 3 запахи: уринозний запах, який власне цікавить нас в даній темі, «odor mali ominis», - запах, помічений (як з'ясував сам вчений пізніше), багатьма закордонними лікарями, не схожий на жоден існуючий в природі запах і з'являється в деяких випадках незадовго до смерті, та запах прілого сіна, характерний для хронічних доброякісних форм туберкульозу.

Уринозний запах, як помічає автор, в деяких працях плутається 3 аміачним, котрий має діагностичну цінність при хронічних циститах, що спричинений бродінням і розкладанням сечовини. 3 цього приводу він приводить чіткі роз'яснення. Також в роботі описано дослідження, проведене в 1912 році в його клініці, що привело до висновку, що запах доволі точно відображує підвищення азоту в крові. Була виділена група пацієнтів з уремією, у яких концентрація азоту крові перевищувала 1.0 pro mille, виявлено, що уринозний запах визначається в $90 \%$ випадків. Тож наведеним висновком була рекомендація при будь-якому випадку нефриту слідкувати за появою цього характерного запаху для раннього виявлення уремії.

Також неможливо лишити поза увагою опубліковану 1928 року в «Клинической медицине» працю «Основы терапевтических мер при мочевых камнях прежде и теперь». Для початку Феофіл Гаврилович виказує думки щодо терапевтичного підходу, а саме - те, що потрібно, аби позбавитися від етіологічного аспекту хвороби або усунути спричинене хворобою зло. Можна порівняти з сучасними підходами до лікування патологічних станів: етіологічний, патофізіологічний та симптоматичний. Далі мова йшла про три види каменів: з сечової кислоти, щавлевої кислоти і фосфатів, які не ускладнені інфекціями. Тоді з опису історії розвитку знань про природу сечокам'яної хвороби можна зрозуміти, що її початок пояснювали подагрою і неврастенічним діатезом. Пізніше з'явилася така наука, як колоїдна хімія, яка надавала своє пояснення цього явища. Ф.Г. Яновський, до речі, за свідченнями його сучасників, особливо цікавився колоїдною хімією наприкінці свого життя. Якщо ж казати саме про тогочасні методи лікування сечокам'яної хвороби, то основною тут була дієта, яка підбиралася в залежності від природи каменів. Феофіл Гаврилович наводить таку цитату Петрарки: «кто хочет не иметь камней, тот пусть живет бедно», маючи на увазі скромність в харчуванні. Окрім дієтики, застосовувались інші методи лікування: кліматичне, бальнеологічне (з урахуванням оцінки психічного стану пацієнта). Також намагалися регулювати кислотно-лужний показник сечі для забезпечення розчинення уратів, оксалатів, фосфатів за допомогою коректно підібраної дієти.

Останньою визначною роботою видатного вченого в галузі нефрології стала доповідь на $\mathrm{X}$ Всесоюзному з'їзді терапевтів (1928) на тему «Сифіліс нирок». В роботі викладені актуальні на той час знання медичної спільноти про сифіліс нирок.

Хотілося б звернути увагу на сифілітичний нефроз, так як з цього приводу Ф.Г. Яновський мав досвід спостереження у своїй клініці. Яскраво окреслена семіотика сифілітичного нефрозу: ранній прояв, різко виражена альбумінурія, швидкий і стрімкий розвиток набряків, характерні ознаки в сечі - мутність, еритроцити і лейкоцити, циліндри, ліпідна зернистість. 3 приводу саме ліпідної зернистості Феофіл Гаврилович має певне зауваження, через те, що цю ознаку можна виявити також при ряді інших захворювань, що позбавляє цей показник діагностичної важливості. Також піддані критиці висловлювання деяких зарубіжних авторів з приводу уремії як вкрай специфічного показника сифілітичного нефрозу, а в якості аргументу наведений клінічний випадок з клініки Ф.Г. Яновського, в якому уремія мала місце на початку, але поступово зникла на фоні прогресування нефрозу, що, як і стосовно попередньої ознаки, позбавляє порушення азотовидільної функції нирок діагностичного значення у випадку даної патології.

Висновки. Слід підкреслити широту наукових інтересів Ф.Г. Яновського: від патофізіологічних, клініко-діагностичних до лікування найпоширеніших захворювань того часу органів дихання, нирок, серця. Всі дослідження були ґрунтовно 
проведені Феофілом Гавриловичем та учнями в його клініці і винесені на обговорення широкою медичною спільнотою.

Особливу увагу приділяють особистості Феофіла Гавриловича Яновського, його гідності, гуманізму, делікатності, саме тільки про нього ширилась слава не тільки як висококваліфікованого лікаря та науковця, але, перш за все, як «святого лікаря» та «лікарську совість». Хотілося, щоб його знали і пам'ятали, бо historia est schola vitae.

Феофіл Гаврилович Яновський був академіком ВУАН, професором Київського медичного інституту і просто щирою інтелігентною людиною. Завідував терапевтичною кафедрою Новобілицього медичного університету в Одесі та кафедрою лікарської діагностики Київського медичного інституту.

\section{ЛITEPATУРА}

1. Диагностика заболеваний почек в связи с их патологией. - К., 1927. - 111 С.

2. К семиотике острых нефритов. // Сб. тр. В честь 30-летия науч.-пед. Деятельности проф. В.К.Высоковича. 1907. - с. 227-236.

3. К современному положению диетики при нефритах.: // Рус. Врач. - 1913. - №34. - с. 1187 1190.

4. Клиническое значение запаха. // Врачеб. Дело. - 1925. - №7. - Стб. 549-556.

5. О способах функционального распознавания почечных болезней . // Рус. Врач. -1913. №6. - с. 169-177.

6. Основы терапевтических мер при мочевых камнях прежде и теперь. // Клин. медицина. - 1928. - №6. - c. 321-330.

7. Сифилис почек. // Тр. 10 съезда терапевтов Союза ССР. 15-20 мая 1928 г. -., 1929 г. C. $162-175$.

8. Шипулін В.П. «Академік Ф.Г. Яновський: грані особистості». - Гастроентерологія 2 (52) 2014. -c. 94-101.

\section{PЕЗЮME}

\section{Ф.Г. ЯНОВСКИЙ: СТРАНИЦЫ ЖИЗНИ,} ДОСТИЖЕНИЯ В НЕФРОЛОГИИ

Шевчук С.Г., Шанчук М.А.

(Киев)

Цель работы: ретроспективный анализ истории Киевской терапевтической школы и вклад Ф.Г. Яновского в развитие нефрологии.
Материалы и методы: нами было проведено знакомство и ретроспективный анализ архивных материалов в том числе печатных работ Ф.Г. Яновского относительно методов обследования, диагностики и лечения болезней почек, в частности, нефритов в его клинике.

Результаты и обсуждение: в роботе приведены результаты и обсуждение семи основных научных работ Ф.Г. Яновского в области нефрологии по результатам обследования и лечения больных в его клинике.

Выводы: учитывая актуальность некоторых аспектов современной нефрологии и взглядов на новейшие подходы к диагностике и лечению, следует подчеркнуть преемственность представителей Киевской терапевтической школы, а также подчеркнуть роль Ф.Г. Яновского как научного работника и личности в медицине.

Ключевые слова: семиотика болезней почек, нефрит, функциональная диагностика, Феофил Гаврилович Яновский.

\section{SUMMARY}

\section{F.G. YANOVSKYI: PAGES OF LIFE, ADVANCES IN NEPHROLOGY}

Shevchuk S.G., Shanchuk M.O.

(Kyiv)

Goal of work: retrospective analysis of history of The Kyiv therapeutic school and contribution of F.G. Yanovskyi to development of nephrology.

Materials and methods: we had an acquaintance and retrospective analysis of archive materials including printing works of F.G. Yanovskyi about methods of examination, diagnostics and treatment of kidney diseases particularly nephritis in his clinic.

Results and discussion: in work presents the results and discussions of seven main scientific works of F.G. Yanovskyi in nephrology based on the results of examination and treating sick people in his clinic.

Conclusions: considering the relevance of some aspects of modern nephrology and glances at the latest approaches to diagnostic and treatment we should emphasize succession of representatives of The Kyiv therapeutic school and also emphasize role of F.G.Yanovskyi as a scientist and personality in medicine.

Key words: semiotics of kidney diseases, nephritis, functional diagnostics, Feofil Gavrilovich Yanovskyi.

\section{Шевчук Світлана Григорівна} sveta.shevchuk@ukr.net 